\title{
Sítios urbanos na redemocratização: novas demandas e caminhos para ampliação das práticas de preservação
}

\author{
Urban sites in redemocratization: new demands and ways to expand \\ preservation practices
}

https://doi.org/10.1590/1982-02672020v28d2e33

\section{LIA MOTTA'}

https:/ / orcid.org/0000-000 1-5297-7890

Instituto do Patrimônio Histórico e Artístico Nacional / Rio de Janeiro, RJ, Brasil

RESUMO: Este artigo trata das respostas às demandas de proteção das cidades feitas por novos agentes sociais à instituição federal de preservação, hoje o Instituto do Patrimônio Histórico e Artístico Nacional (lphan), de 1979 até 1989, durante o processo de redemocratização do Brasil. Problemas urbanos, intensificados na década de 1970, envolvendo a destruição de áreas das cidades, assim como transformações nos sítios tombados, provocaram mudanças na valorização desses bens culturais, uma vez que as demandas de proteção não necessariamente correspondiam aos padrões até então usados para proteção das cidades pela instituição federal de preservação. Até então as ações de preservação se estruturavam tendo como agentes sociais intelectuais modernistas e uma visão hegemônica do que seria a representação de uma identidade nacional: arquitetura colonial brasileira e imóveis considerados excepcionais. No atendimento aos novos pedidos de proteção, foram adotados outros valores de patrimônio, admitindo-se uma heterogeneidade de estilos arquitetônicos nos sítios, a historicidade urbana e assumindo o conceito cidade-documento na superação do critério estilístico de valoração das cidades. A instituição aproximou-se dos habitantes dos sítios tombados e promoveu ações de produção de conhecimento para o estabelecimento de parâmetros e normas de análise das intervenções solicitadas por eles. Destaca-se a Constituição Federal de 1988, por ser a primeira que definiu um conceito orientador das práticas de preservação e por ter os grupos sociais como protagonistas da valorização dos bens culturais.

PALAVRAS-CHAVE: Patrimônio urbano. Redemocratização. Demandas sociais. Cidadedocumento. Historicidade urbana.

\begin{abstract}
1. Graduada em Arquitetura e Urbanismo pela Universidade Federal do Rio de Janeiro (UFRJ), especialista em Conservação e Restauração de Sítios e Monumentos Históricos pela Universidade Federal de Minas Gerais (UFMG), mestre em Memória Social pela Universidade Federal do Estado do Rio de Janeiro (Unirio) e doutora em Urbanismo pela UFRJ. Atualmente é docente do Mestrado Profissional em Preservação do Patrimônio Cultural do Iphan. E-mail: $<$ liamotta78@gmail.com>.
\end{abstract}


ABSTRACT: This article deals with the responses to the demands of protection of cities made by new social agents to the federal institution of preservation, from 1979 to 1989, during the process of redemocratization in Brazil. Urban problems, intensified in the 1970s, involving the destruction of urban areas, as well as transformations in the listed sites, caused changes in the valuation of these cultural goods, since the demands did not necessarily correspond to the standards previously used to protect cities by the federal preservation institution. Until then modernist intellectual agents structured preservation actions and a hegemonic vision of what would represent a national identity: Brazilian colonial architecture and exceptional buildings. In response to new requests, other heritage values were adopted, admitting the heterogeneity of architectural styles on the sites, the urban historicity, and assuming the concept of city's as documents in overcoming the stylistic criteria of valuing towns. The institution approached the inhabitants of the listed sites and promoted research for the production knowledge to establish parameters and analysis standards for the interventions requested by them. The 1988 Federal Constitution stands out, for being the first to define a guiding concept for preservation practices and for having social groups as protagonists in the valorization of cultural goods.

KEYWORDS: Urban heritage. Redemocratization. Social demands. City's as documents. Urban historicity. 


\section{INTRODUÇÃO}

Nas décadas de 1970 e 80, com o Brasil em processo de redemocratização, quando movimentos sociais se fortaleceram com manifestações pelo respeito à diversidade cultural e às cidades, as instituições de preservação do patrimônio cultural receberam novas demandas pela proteção de bens culturais, nem sempre semelhantes aos que haviam sido valorizados para preservação até então. Foram momentos de formulação de novos discursos pelas diferentes instâncias governamentais - municípios, estados e governo federal -, apresentando o conceito de bem cultural, de ambiente cultural urbano, de cidade-documento, a ideia de comunidade como melhor guardiã de seu patrimônio e de inclusão dos bens culturais populares como parte do patrimônio a ser protegido pelo poder público. Na proteção dos sítios urbanos, admitiu-se uma heterogeneidade de estilos arquitetônicos, valorizando a historicidade urbana, extrapolando o valor da uniformidade estilística e a exclusividade de valorização da arquitetura colonial, tradicionalmente protegida no Brasil. Destaca-se a Constituição Federal de 1988 que, naquele momento de transformações nas práticas de preservação, definiu pela primeira vez, num documento dessa importância, um conceito orientador para o assunto, tendo os grupos sociais como protagonistas da valorização dos bens como referências culturais, abrindo inúmeras possibilidades para sua proteção.

Embora reconhecendo a importância da participação de outras instâncias do poder público na busca de alternativas para ações mais amplas de preservação, este artigo abordará as práticas da instituição federal, hoje Instituto do Patrimônio Histórico e Artístico Nacional (lphan), na proteção de sítios urbanos, entendendo que as demandas pela proteção desses bens e por transformações nos centros históricos já tombados estimularam o desenvolvimento de uma atitude institucional mais democrática. Escrever sobre esses acontecimentos pode contribuir para a compreensão da trajetória da preservação no Brasil e para reflexões a respeito de sua continuidade, necessárias ainda hoje, para a ampliação da preservação das cidades de acordo com a definição constitucional de patrimônio.

Mesmo sabendo que as novas demandas pela preservação começaram no início dos anos 1970, aqui será privilegiado o período em que elas aconteceram em maior quantidade e no qual a redemocratização do país ganhou força: de janeiro de 1979 até o final de 1989. Não por acaso, desde a suspensão do Ato Institucional n. 5 (Al-5) pelo governo militar da ditadura iniciada em 1964, com a restauração da liberdade de associação, ${ }^{2}$ até a eleição direta do primeiro presidente de República pós-ditadura. Para este texto foram consultados os processos de tombamento abertos pela instituição federal de preservação, cujas
2. A suspensão do AI-5 foi anunciada em outubro de 1978 para ter validade a partir de janeiro de 1979. 
3. Os períodos foram: Iphan - Instituto do Patrimônio Histórico e Artístico Nacional, de 1970 até 1979; Sphan - Secretaria do Patrimônio Histórico e Artístico Nacional, de 1979 até 1981; Sphan - Subsecretaria do Patrimônio Histórico e Artístico Nacional, de 1981 até 1985; voltando a ser Sphan - Secretaria do Patrimônio Histórico e Artístico Nacional, de 1985 até 1990.

4. Cf. Rezende et al. (2015).

5. Cf. Nascimento (2015). denominações ao longo dos dez anos aqui tratados foram Instituto do Patrimônio Histórico e Artístico Nacional (Iphan) e Secretaria e Subsecretaria do Patrimônio Histórico e Artístico Nacional (Sphan). ${ }^{3}$ Também foram consultados documentos relativos aos seminários promovidos pela instituição nos centros históricos tombados de 1979 a 1982, o Inventário Nacional de Imóveis em Sítios Urbanos Tombados (INBI-SU), implantado em 1987, assim como fontes bibliográficas. Cabe esclarecer que no mesmo período a instituição contou com o reforço da Fundação Nacional Pró-Memória (Pró-Memória), criada em dezembro de 1979 para ser seu braço executivo, dando mais agilidade às ações de proteção do patrimônio cultural, sem a perda do caráter normativo, a cargo do Iphan e da Sphan. ${ }^{4}$

\section{SOBRE AS DEMANDAS SOCIAIS}

Na história da preservação no Brasil, dois momentos foram marcantes no que diz respeito à participação social pela preservação: as décadas de 1920 e 1930, quando intelectuais modernistas se empenharam pela proteção de determinados bens que, no seu entender, representavam a identidade nacional, e o momento desenvolvido neste texto - as décadas de 1970 e 1980 -, de reivindicações de grupos sociais, indivíduos, instituições e políticos pela preservação, destacando-se aqui aquelas feitas para a proteção dos sítios urbanos.

Ao grupo de modernistas devemos a importância e o respeito que o campo do patrimônio alcançou e a criação do Serviço do Patrimônio Histórico e Artístico Nacional (Sphan), hoje instituto, com mais de 80 anos de idade. Mas esse grupo também foi responsável pela compreensão do valor de patrimônio a partir de estilos, privilegiando inicialmente as características coloniais dos sítios urbanos e imóveis. A essas características foi atribuído por eles um valor como referência de uma identidade nacional, por ser uma produção resultante da adaptação da arquitetura portuguesa ao território da colônia, aos seus materiais e à sua mão de obra, não se limitando simplesmente à importação de estilos e técnicas de Portugal. $\bigcirc$ empenho dos intelectuais modernistas na proteção da arquitetura e arte colonial para viabilizar o seu projeto de nação incluiu sua associação ao governo de Getúlio Vargas, contribuindo para a criação do Serviço e com seu engajamento nos quadros profissionais da instituição. $\bigcirc$ arquiteto Lucio Costa foi um desses senvidores, participando dos trabalhos de valorização dos sítios e monumentos desde o início dos trabalhos de preservação no Brasil. ${ }^{5}$ Outro critério de valorização incluía, como passíveis de proteção pelo Sphan, bens 
considerados excepcionais ou relacionados a fatos memoráveis da história, conforme definia o Decreto-Lei 25 de 1937 que regulamenta a proteção pelo tombamento.

Estudos de Silvana Rubino e Marcia Chuva abordam esse tema, mostrando o que foi protegido nas práticas iniciais de preservação do patrimônio nacional. Segundo Rubino, em 1967, quando o Iphan (então diretoria - Dphan) completou 30 anos, estavam tombados 689 bens culturais, sendo 645 bens arquitetônicos e sítios urbanos e 44 de outras categorias. Dentre os bens arquitetônicos e sítios urbanos, 93,62\% eram de características coloniais. ${ }^{6}$ Ressalte-se que em 1938 foram tombados seis conjuntos arquitetônicos, urbanísticos e paisagísticos em Minas Gerais: Diamantina, Mariana, Ouro Preto, Serro, São João del-Rei e Tiradentes.

Para Marcia Chuva, o colonial mineiro foi legitimado como patrimônio cultural e as ações da instituição, desde sua fase inicial, de 1937 a 1945, construíram um quadro da memória coletiva, conforme entendimento do sociólogo Maurice Halbwachs, por meio do qual se passou a compreender o valor do passado. Em suas palavras essa arquitetura:

[...] alcançou tal legitimidade e reconhecimento, que se pode pensar, na perspectiva de Maurice Halbwachs, que a partir dela e sempre a ela relacionados, foram, em boa medida, consubstanciados os "quadros da memória coletiva", entendida como aquela que compõe magicamente o passado, a partir da memória dos quadros de um grupo, que passam a ser, por sua vez, os quadros comuns a toda uma sociedade em que esse grupo domina.?

O segundo momento, nas décadas de 1970 e 1980, foi marcado pelas demandas por diferentes agentes pela proteção do patrimônio urbano, sem a unidade do movimento modernista, quando essa proteção passou a ser vista como meio para conquista da manutenção de áreas das cidades e, consequentemente, de sua qualidade de vida. ${ }^{8}$

É importante lembrar que no período da ditadura civil-militar um dos motores da política econômica era a indústria da construção civil, implicando a destruição de áreas urbanas. Entretanto, havia também o favorecimento do patrimônio cultural pelo governo militar, o que, em certa medida, beneficiava as novas reivindicações pela proteção de sítios urbanos. Na década de 1970 estes foram objeto de investimento daquele governo, destacando-se a criação do Programa das Cidades Históricas (PCH) por meio de um convênio entre Secretaria de Planejamento e Coordenação Geral da Presidência da República e o Iphan. ${ }^{9}$ Segundo Paulo Ormindo de Azevedo, o PCH foi o "maior programa de preservação do patrimônio cultural integrado a um plano de desenvolvimento urbano e regional, por meio do
6. Cf. Rubino (1996).

7. Chuva (1998, p. 55).

8. Além dos pedidos de tombamento dirigidos ao Iphan, havia a demanda de redução de gabaritos dos prédios por meio do uso do instrumento do entorno de bens tombados, como forma de desestimular a especulação imobiliária, e a preservação de áreas urbanas era solicitada às prefeituras e governos estaduais. Cf. Lia Motta (2000).

9. Esse programa foi criado em 1973, inicialmente chamado de Programa Integrado de Reconstrução das Cidades do Nordeste, sendo ampliado em 1975 para todo o Brasil como Programa das Cidades Históricas (PCH). 
10. Azevedo (2016, p. 238).

11. Ibid. p. 238.

12. Miceli (1984, p. 100).

13. Ibid. p. 102.

14. Ibid. p. 106.

15. Ibid. p. 106.

16. O CNRC foi criado como um projeto do Ministério da Indústria e do Comércio, contando com o apoio do Governo do Distrito Federal e da Universidade Federal de Brasília. A respeito da proposta do Centro cf. Sphan/PróMemória (1980).

17. Aloísio Magalhães abordou esse assunto no Seminário Perspectivas do Ensino em Brasília, em 1976, quando referiuse aos riscos do processo de globalização, cujo resultado poderia ser a perda das "peculiaridades" da cultura brasileira pela absorção inadequada de valores importados de outras culturas. Magalhães (1997, p. 256). turismo cultural"..$^{10} \mathrm{E}$ fazia parte do planejamento para o desenvolvimento econômico que, no entender do governo, poderia contribuir para diminuir conflitos no Nordeste, "então conflagrado por movimentos sociais no campo, e uma das maiores preocupações dos militares", "1 conforme observado por Azevedo.

Para Sergio Miceli, na década de 1970 "ocorreram transformações importantes nos conteúdos e nas orientações da política cultural oficial no tocante ao trabalho de conservação do patrimônio histórico e artístico 'nacional'". ${ }^{12} \bigcirc$ contexto favorecia os temas da preservação do patrimônio cultural, como um "repositório de obras do passado sobre cujo interesse histórico, documental e, por vezes, estético não paira qualquer dúvida. Trata-se de obras e monumentos que, no mais das vezes, já se encontram dissociados das experiências e interesses sociais que thes deram origem". ${ }^{13}$

Miceli ressaltou que no documento do governo federal "Política Nacional de Cultura", editado pelo Ministério de Educação e Cultura (MEC) em 1975, primeiro a veicular um discurso oficial relacionado ao tema da cultura, demonstrava-se a urgência da salvaguarda do patrimônio cultural pelo poder público e que a noção de patrimônio apresentada envolvia "tanto o acervo associado à história dos grupos dirigentes como as tradições e costumes das classes populares definidas como folclore ou populário". ${ }^{14} \bigcirc$ uso desse patrimônio era considerado como núcleo de uma cultura brasileira autônoma, com características próprias e capazes de se opor à massificação do desenvolvimento e dos meios de comunicação numa clara preocupação com a identidade cultural brasileira frente à globalização. Para Miceli havia o

[...] intuito de "preservar um núcleo irredutível de cultura autônoma que imprima feição própria ao teor da vida brasileira". Pretende-se, por essa via, erigir um dique "caracteristicamente nosso" em condições de auxiliar a triagem de traços culturais "perversos" produzidos pelo desenvolvimento urbano-industrial e de sustar a imposição maciça, através dos meios de comunicação, dos valores estrangeiros. A meta "patrimonial" serve, ao mesmo tempo, para definir pautas próprias de ałuação governamental e suprir de conteúdos e significações da "alma brasileira" as metas de segurança e desenvolvimento. ${ }^{15}$

Nesse contexto o Iphan foi fortalecido sob o comando do designer e advogado Aloísio Magalhães egresso do Centro Nacional de Referência Cultural (CNRC), do qual foi diretor e o principal responsável por sua criação, em 1975.16 Tal Centro tinha como objetivo desenvolver pesquisas para o referenciamento da cultura brasileira, dedicando-se, principalmente, à produção popular pré-industrial, entendida como bens culturais vivos e ameaçados de perder suas "peculiaridades" em face da globalização. ${ }^{17}$ Segundo José Quintas, pesquisador do CNRC, eles 
trabalhavam "mais a Cultura enquanto processo do que enquanto produto". ${ }^{18}$ Isto é, os bens, nessa visão, eram valorizados por causa dos contextos culturais de sua produção, dos modos de fazer e saberes dos seus produtores.

Ao assumir o Iphan em 1979, Magalhães tinha como objetivo ampliar os trabalhos de preservação com o envolvimento de uma diversidade de bens culturais e, segundo seu entendimento, com base em ideias mais abrangentes de patrimônio, propondo a adoção do conceito de bem cultural e não mais a ideia de valorização do "patrimônio histórico e artístico nacional", conforme definido no Decreto-Lei 25/1937. Magalhães, ao transformar o Iphan na Sphan e criar a Pró-Memória, possibilitou a contratação de pessoal e a incorporação do CNRC e do PCH à nova instituição. Foram criadas, portanto, melhores condições para uma revisão conceitual de patrimônio e para a preservação dos bens culturais. As ações tradicionalmente desenvolvidas pelo Iphan tiveram continuidade e novos valores ganharam atenção, como vinha sendo desenvolvido pelo CNRC. Os modos de fazer e produtos populares passaram a condição de patrimônio intangivel, ou de natureza imaterial, conforme veio a ser chamado pela Constituição Federal de 1988. A transformação institucional pode ser entendida como parte das políticas de patrimônio do governo militar, citadas por Azevedo e Miceli, mas também como adequação necessária ao atendimento às novas demandas da sociedade pela preservação no período da redemocratização.

Cabe citar, também, o contexto mais amplo dos movimentos sociais urbanos, nos anos 1970 e 1980, importantes para compreensão da força das demandas externas pela preservação. Estudiosos analisam, majoritariamente, os grupos menos favorecidos, registrando reivindicações como a melhoria dos transportes públicos, redes de água e esgoto, construção de novas escolas e a posse da terra urbana. ${ }^{19}$ Entretanto, pode-se destacar o estudo de Renato Boschi sobre associações de bairros de classe média e alta no Rio de Janeiro, identificando a criação de 40 associações formadas entre 1969 e 1981, dentre as quais 30 foram criadas nos três últimos anos desse período. Segundo o autor, essas associações foram compostas, predominantemente, por uma nova classe média urbana mais numerosa e bem informada, contando com profissionais liberais e professores, em boas condições de organização e reivindicação. Ele refere-se ainda à "abertura políitica", incluindo a supressão do Al-5, e a outros motivos, como a tendência recessiva da economia com impacto no nível de emprego e renda, diminuindo os ganhos obtidos com o "milagre econômico" e fazendo com que a classe média emergisse como oposição importante ao governo militar. A mobilização dessas associações de classe média e alta se dava em torno de problemas como "a criação de um parque, o corte de uma árvore centenária, a construção de uma autoestrada na área - em suma, projetos relacionados à qualidade de vida
18. Quintas (1994, p. 12).

19. Cf. Moisés; Martinez-Alier (1978) e Boschi; Valadares (1983). 
20. Boschi (1987, p. 69).

21. Cf. Iphan (16 mar. 2016).

22. A Universidade Federal do Acre solicitou o tombamento da casa de Plácido Domingues, em Xapuri, e a partir de entendimentos com o Iphan o estudo foi ampliado para o centro histórico da cidade. urbana". ${ }^{20}$ Mesmo fazendo reivindicações distintas, ainda segundo Boschi, a articulação dessas associações com as de bairros carentes dos subúrbios, de favelas e de conjuntos residenciais populares situados em bairros da classe média e alta, promovida pela Federação das Associações de Moradores do Estado do Rio de Janeiro (Fameri), criada em 1978, conferia a todos uma força política importante.

Embora esses teóricos citem a preocupação com o funcionamento das cidades, sua qualidade de vida e meio ambiente sem relacioná-los à preservação histórica, este tema fazia parte das reivindicações de movimentos sociais urbanos. Isto pode ser constatado nos documentos encontrados no Arquivo Central do Iphan - Seção Rio de Janeiro (ACl-R), onde estão arquivados muitos pedidos de proteção de bens culturais. Tendo como recorte apenas as solicitações de tombamento de "conjuntos urbanos", conforme classificação do Iphan na lista "Bens tombados e processos de tombamento em andamento", ${ }^{21}$ e considerados apenas os processos de tombamento abertos de 1979 a 1989, constata-se que, dos 33 processos abertos no período, 24 têm origem em demandas de agentes externos à instituição e nove têm origem na própria instituição, concluindo-se que $73 \%$ resultaram de demandas externas. Constam entre estes solicitantes: associações de moradores e amigos de bairros, grupos organizados em movimentos espontâneos que organizaram abaixo-assinados, cidadãos e grupos de cidadãos, sendo 12 solicitações, ou seja, 50\% do total; seguidos por seis solicitações de instituições da administração municipal e estadual; de quatro pedidos de deputados estaduais e de dois pedidos do reitor da universidade do Acre.22

As demandas externas abrangem todas as regiões do país e sítios urbanos situados em municípios de diferentes portes: Corumbá/MS e Cuiabá/MT, no CentroOeste; Belém/PA, Natividade/TO, Porto Acre/AC e Xapuri/AC, no Norte; Delmiro Gouveia/AL, Maceió/AL, Penedo/AL, Itabuna/BA e Aracaju/SE, no Nordeste; Magé/RJ, Petrópolis/RJ, Santo André/SP, São Paulo/SP e Serro/MG, no Sudeste; Florianópolis/SC, Laguna/SC, Paranaguá/PR e São Francisco do Sul/SC, no Sul.

A respeito das características dos sítios urbanos, observa-se que alguns se assemelhavam ao que tradicionalmente era valorizado pelo Iphan, com integridade na estrutura colonial e a presença ainda importante de imóveis de características coloniais e escala urbana uniforme. Diferem, no entanto, dos sítios tradicionalmente valorizados por apresentarem imóveis de diferentes estilos, incluindo exemplares do século XIX e XX, como Laranjeiras/SE, Natividade/TO, São Francisco do Sul/SC e a Vila do Ribeirão da llha em Florianópolis/SC, neste caso objeto de dois pedidos de tombamento em 1986 e em 1988. Há sítios urbanos de estrutura colonial, mas cujos contextos ou entornos imediatos abrigavam prédios mais recentes de gabaritos altos que comprometiam a uniformidade da escala colonial, sendo Cuiabá/MT, Laguna/SC, Penedo/AL, 
- Conjunto Arquitetônico e Paisagístico do Largo das Mercês e a Cidade Velha e Campina em Belém/PA e Paranaguá/PR, também objeto de dois pedidos de tombamento, um em 1983 e outro em 1988. Além disso, encontram-se sítios com origem mais recente, como o conjunto monumental, eclético, em Aracaju/SE; Petrópolis/Rj; as vilas operárias de Fernão Velho em Maceió/AL e Delmiro Gouveia/AL; Xapuri/AC; a Vila Ferroviária de Paranapiacaba, em Santo André/ SP, os bairros Jardim América, Jardim Europa, Jardim Paulista e Jardim Paulistano, na capital paulista. Em Magé/RJ, as "Vila da Estrela e Vila Inhomirim", embora classificadas pelo Iphan como "conjuntos urbanos", são sítios em avançado estado de arruinamento, equivalendo hoje, no nosso entender, a sítios históricos arqueológicos, como pode ser, também, o caso da Vila Porto Acre/AC. O sítio urbano de Ferradas, no município de Itabuna-BA, foi onde nasceu Jorge Amado, justificando o pedido de tombamento feito por um grupo de artistas e intelectuais da região. O distrito de São Gonçalo do Rio das Pedras em Serro/MG é o conjunto urbano que ainda mantinha sua integridade colonial.

Ainda segundo a lista do Iphan, "Bens tombados e processos de tombamento em andamento", dos 24 processos com origem em demandas de agentes externos à instituição, 12 foram tombados, sendo quatro na década de 1980, cujas informações serão exploradas adiante: Petrópolis/RJ em 1982, Laguna/SC em 1985, São Francisco do Sul/SC em 1987, Natividade/TO também em 1987. Posteriormente mais 11 sítios foram inscritos nos livros de tombo e dois processos foram anexados aos de outros sítios tombados, equivalendo a uma concordância com seus tombamentos. Além disso, seis processos ainda estão em instrução e apenas quatro foram arquivados. ${ }^{23}$

De modo geral foram dois os critérios orientadores da valorização dos sítios urbanos como patrimônio cultural: o da historicidade urbana, considerando as transformações na arquitetura ao longo do tempo, e o que considerava os vestígios da história impressos nos territórios, abrangendo outros aspectos morfológicos, além da arquitetura e suas transformações, destacando-se, nesse caso, o uso do conceito cidade-documento.

\section{A HISTORICIDADE URBANA NA VALORIZAÇÃO DOS SÍTIOS}

Deve-se observar que a historicidade urbana foi assunto de Rodrigo M.F. de Andrade, primeiro diretor-geral da instituição, no final de sua gestão, na década de 1960. Em texto preparado para Organização das Nações Unidas para a Educação, a Ciência e a Cultura (Unesco), ele empregou o termo "sítio urbano" reconhecendo
23. Os seis processos em instrução são dos seguintes conjuntos urbanos: Xapuri/ AC, Vila Operária em Delmiro Gouveia/AL, Vila Operária em Fernão Velho, em Maceió/AL, Distrito de São Gonçalo do Rio das Pedras, em Serro/MG, Vila da Estrela e Vila Inhomirim, em Magé/RJ, e os bairros Jardim América, Jardim Europa, Jardim Paulista e Jardim Paulistano, em São Paulo/SP. Os quatro processos indeferidos são: Porto Acre/AC, Ferradas em Itabuna/BA, o segundo processo de tombamento de Paranaguá/PR e um conjunto monumental, eclético, em Aracaju/SE. 
24. O texto foi publicado em inglês na série da Unesco "Museums and Monuments XI" The Conservation of Cultural Property, em 1968, e foi editado em português na coletânea de textos Rodrigo e o Sphan, em 1987. Cf. Andrade (1987).

25. Cf. Processo n ${ }^{\circ} 847-\mathrm{T}$ 1973, Lençóis/BA (1973).

26. Processo no 1201-T-1986, Penedo/AL (1986, fl. 2).

27. Ibid. fls. 143-145.

28. Ibid. fls. 182-183. que as cidades eram resultado de diferentes fases da sua história. ${ }^{24}$ Esse critério de valorização de sítios urbanos foi praticado já na década de 1970, sendo necessário que os sítios mantivessem uma escala considerada harmoniosa. Foi o caso do centro histórico de Lençóis, na Bahia, cujo tombamento federal, solicitado ao Iphan pelos governos municipal e estadual em 1972, obteve resposta positiva, admitindo-se a presença de exemplares do século XIX em conjugação com a arquitetura colonial original da cidade, pela harmonia, ainda presente, na conjugação dos estilos. ${ }^{25}$

$\bigcirc$ critério, empregado mediante essa harmonia e a uniformidade da escala urbana, comprometeu outros tombamentos como, por exemplo, o tombamento do centro histórico de Penedo, em Alagoas. Viana de Lima, arquiteto consultor da Unesco, em Missão no Brasil a convite do lphan na década de 1970, considerou a cidade importante para proteção, pela sua arquitetura e seu potencial para o turismo, mas o sítio não mereceu a atenção da instituição federal na ocasião. Mesmo depois, quando em 1986 foram feitos dois pedidos de tombamento da cidade, por um deputado estadual e pelo Rotary Clube de Penedo, o diretor regional da Sphan/Pró-Memória, ao encaminhá-los à presidência da instituição, manifestou-se contrário ao seu atendimento. Para ele, o volume do edifício do Hotel São Francisco (figura 1), exemplar modernista da década de 1950, com oito pavimentos, e as novas construções na cidade eram perturbadoras da integridade do conjunto urbano. Em suas palavras:

Infelizmente, há a lamentar a construção do Hotel São Francisco, localizado num dos mais altos pontos da cidade, que, pela sua grande volumetria e traços arquitetônicos fera profundamente a ambiência, descaracterizando grosseiramente a paisagem, isto, além de inúmeras outras construções de épocas mais recentes, perturbadoras das linhas específicas do conjunto urbano. ${ }^{26}$

conjunto arquitetônico, paisagístico e urbanístico de Penedo foi tombado em 1996, após nova solicitação de tombamento feita em 1994 por meio de abaixo-assinado de cidadãos da cidade e encaminhada ao lphan pela prefeitura municipal. ${ }^{27} \bigcirc$ tombamento resultou das transformações nos critérios de valorização dos sítios, considerando as novas intervenções arquitetônicas como parte da historicidade urbana e do conceito cidade-documento. Na justificativa do tombamento, feita pelo Departamento de Proteção da área central do Iphan, foi transcrita parte do parecer elaborado na década de 1980 por Luiz Fernando P.N. Franco a respeito de Laguna, em Santa Catarina, no qual foi adotado, pela primeira vez, o conceito cidade-documento na Sphan/Pró-Memória. ${ }^{28}$ Desse modo, o estudo de tombamento de Penedo deu continuidade ao uso do conceito cidade-documento, como narrativa de valorização das cidades para a ampliação 
do atendimento às demandas de proteção, abrindo espaço para ações institucionais mais democráticas, como será visto na próxima seção.

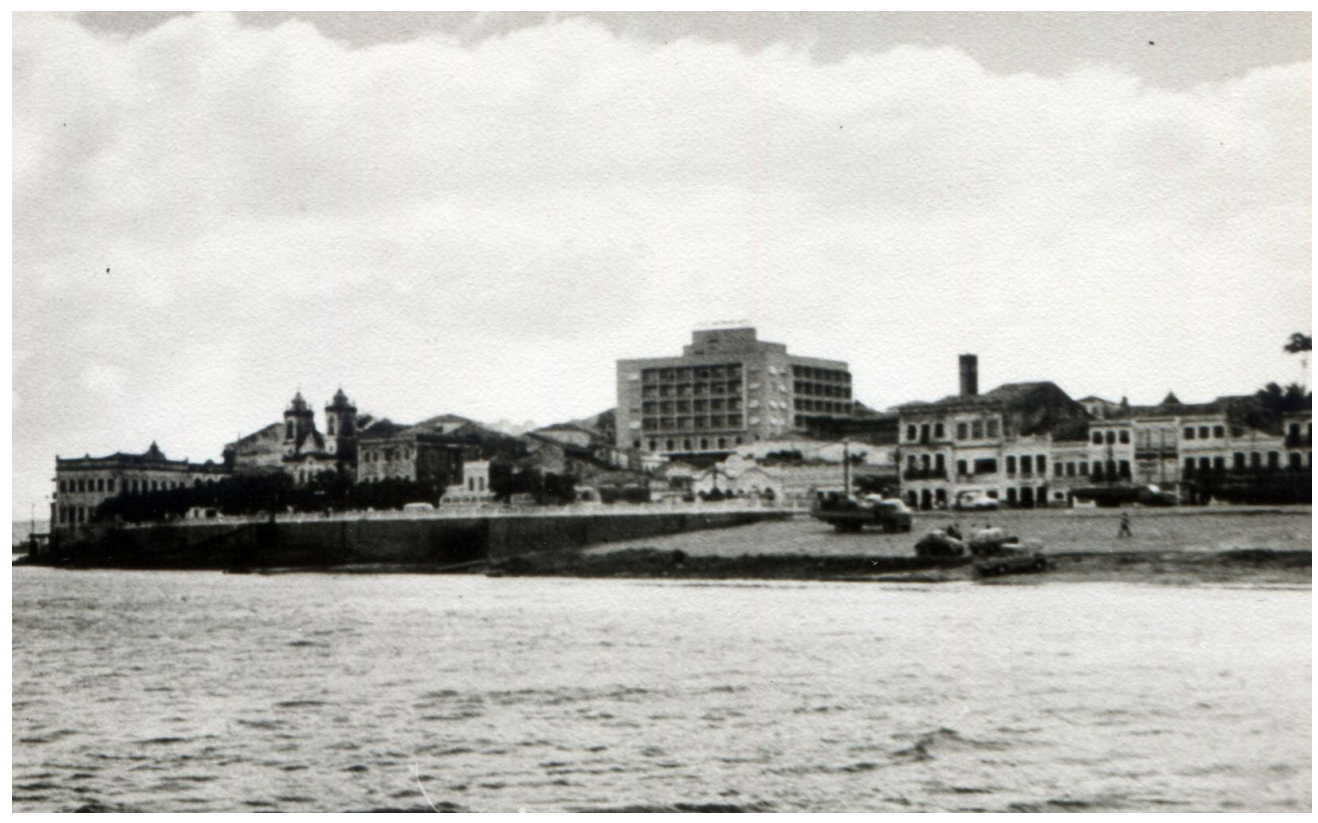

Figura 1 - Vista de Penedo/AL, a partir do Rio São Francisco, na qual se pode ver o Hotel São FrancisCo, único prédio alto na paisagem. Foto: Viana de Lima, 1976. Relatório de Missão da Unesco, ACl-RJ.

\section{A CIDADE-DOCUMENTO COMO ESTRATÉGIA DEMOCRÁTICA}

A cidade-documento foi o conceito adotado para a orientação de uma nova visão de cidade como patrimônio no atendimento às demandas pelo tombamento de sítios que não se assemelhavam àqueles tradicionalmente protegidos pelo Iphan e para valorização da forma urbana, independentemente dos estilos arquitetônicos que a compunham. $\bigcirc$ conceito tem como princípio a leitura da cidade nos seus diversos aspectos morfológicos, como resultado de uma construção social que contemplou diferentes possibilidades de ocupação dos espaços, interesses e forças em disputa. Assim como os documentos, entendia-se que a forma urbana deve provocar perguntas dos pesquisadores para a compreensão de seus significados e para a valorização de seus diferentes aspectos. Trata-se da leitura da história da cidade impressa no território, apoiada por sua representação em planta cadastral e outros documentos: uma dialética entre diferentes fontes e tipos de informações, incluindo a paisagem urbana, devendo resultar na sua transformação em documento. 
29. Cf. Bloch (1965).

30. Cf. Le Goff (1984).

31. São referência urbanistas como Saverio Muratori, Gianfranco Caniggia, Gian Luigi Maffei, Paulo Maretto e Gian Franco Di Pietro, que adotavam o conceito cidade-documento.

32. Destaca-se o texto em que Franco descreve o método de análise do centro histórico de Belém, publicado nos Anais do II SEDUR - Seminário sobre desdenbo urbano no Brasil (1986).

33. Rezende (2007a, p. 146).
Não se pode esquecer que esse conceito tinha como base a concepção de história formulada ao longo do século XX, desde a Escola dos Analles até a Nova História, por autores como Marc Bloch ${ }^{29}$ e Jacques Le Goff. ${ }^{30}$ Uma transformação importante ao longo desse período foi exatamente a noção de documento que, diferentemente da noção empregada no século XIX, passou a ser entendido como escolha do pesquisador que os cria a partir de problemas e questões específicas do tempo presente. Documentos não seriam apenas os escritos, mas tudo que pudesse ser analisado e interpretado na produção de narrativas da história e a construção de memórias e identidades. As cidades, nessa perspectiva, podem ser objeto de leitura tanto quanto os documentos escritos. Novos caminhos se abriram para a sua compreensão e tratamento, como patrimônio cultural, quando essas ideias foram adotadas no urbanismo, principalmente por arquitetos italianos. ${ }^{31}$

Franco, citado anteriormente, estudou e trabalhou na Itália, trazendo o conceito cidade-documento para a instituição quando contratado pela Pró-Memória, em 1983, integrando-se à Diretoria de Tombamento e Conservação (DTC), da área central da Sphan/Pró-Memória. Além de adotar o conceito no estudo de tombamento de Laguna e na produção de textos sobre a cidade-documento, ${ }^{32} \mathrm{em}$ 1989, no "Seminário Inventário de Centros Históricos: avaliação e perspectiva de utilização dos dados", Franco usou estas palavras em sua definição:

Implícita na noção de documento está a valorização de uma linguagem própria do sítio urbano - a linguagem da forma, na qual encontramos expressão e significados. Os homens socialmente organizados moldam os materiais, dando a eles uma forma que se constitui numa linguagem que pode ser lida e interpretada. É importante lembrar que a noção de forma aqui referida não se limita àquela que representa um estilo ou uma estética, mas àquela que expressa toda a série de operações que caracteriza a vida do homem no seu modo de estar no mundo [...] A forma é o resultado dos materiais e do território natural moldados diante das possibilidades e limites dos homens ao se apropriarem de um espaço e de estruturas preexistentes ao longo do tempo. ${ }^{33}$

O tombamento do centro histórico de Laguna, inscrito nos livros de Tombo Histórico e no Arqueológico, Etnográfico e Paisagístico, em 1985, tornou-se o caso emblemático no qual foi explicado o conceito cidade-documento. Entretanto, cabe ressaltar que antes disso, de 1980 a 1982, o tombamento de Petrópolis, no Rio de Janeiro, foi desenvolvido com base na leitura da ocupação do território como um documento, embora anterior à sua teorização da cidade-documento.

Em 1979, por causa da intensa especulação imobiliária que vinha destruindo imóveis em Petrópolis para a construção de prédios com até 15 
pavimentos (figura 2), a Associação Amigos de Petrópolis (Apand) encaminhou um Anteprojeto de Lei ao Congresso Nacional para a preservação do patrimônio cultural e natural da cidade, até então, contando apenas com o tombamento de palácios e da Avenida Koeler, um de seus eixos monumentais. Ao tomar conhecimento do anteprojeto, a direção do Iphan considerou a proposta demasiadamente ampla e vaga, sem efetividade legal para proteção do sítio, uma vez que na forma de lei do Congresso Nacional tal proteção não passaria pelos procedimentos administrativos exigidos para o tombamento. ${ }^{34}$ Isso levou Aloísio Magalhães a negociar o desenvolvimento de uma proposta de proteção da cidade, envolvendo os governos estadual, municipal, a direção central da Sphan/Pró-Memória e a sociedade civil, tendo à frente a Apand.

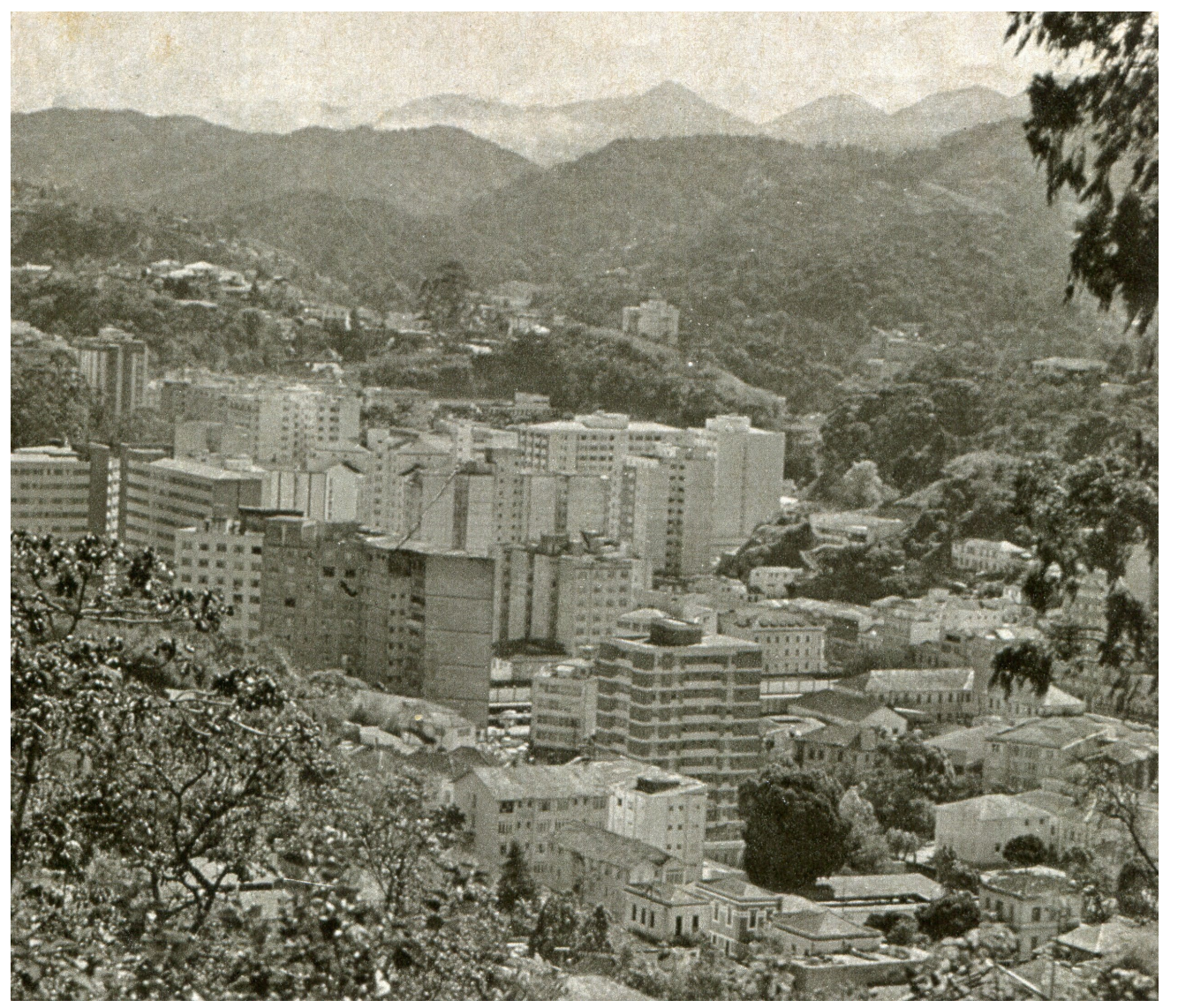

Figura 2 - Fotografia da Revista Isto É, de $1^{\circ}$ de outubro de 1986, cujo título é "Petrópolis vista do Morro do Caxambu: devastação imobiliária". Foto: Antônio Augusto, 1986. Série Inventário, ACl-RJ.
34. Sobre o tombamento como um ato administrativo deve-se ressaltar sua importância como procedimento democrático, uma vez que é por meio dos processos administrativos que são discutidos e fundamentados os valores atribuídos aos bens, envolvendo diferentes agentes sociais, técnicos e representantes da sociedade civil nos conselhos de tombamento. Com base na fundamentação e atribuição de valores devem ser estabelecidos os critérios de preservação, sempre considerando o interesse público da preservação, também, de responsabilidade do poder executivo, não cabendo ao judiciário esses procedimentos. Cf. Rabello (2015). 
Esse estudo resultou no Projeto Petrópolis - Planejamento e Preservação, coordenado pela Fundação de Desenvolvimento da Região Metropolitana do Rio de Janeiro (Fundrem), do governo estadual. Na valorização do sítio como patrimônio cultural foram considerados os condicionantes geográficos da forma urbana, desenhada pelo engenheiro alemão Julius Friedrich Koeler, em 1846 (figura 3). Esse desenho organizou a cidade ao longo das calhas dos rios e canais, entre os morros, e com lotes que serviriam a diferentes propósitos: de maiores dimensões para colonos e a produção agrícola, e menores para as famílias das elites, próximos do Palácio Imperial. Além dessa forma urbana inicial, foram valorizados, para proteção como patrimônio cultural, os imóveis da indústria têxtil, participantes da evolução histórica de Petrópolis. A maior parte da cidade, portanto, ficou protegida.

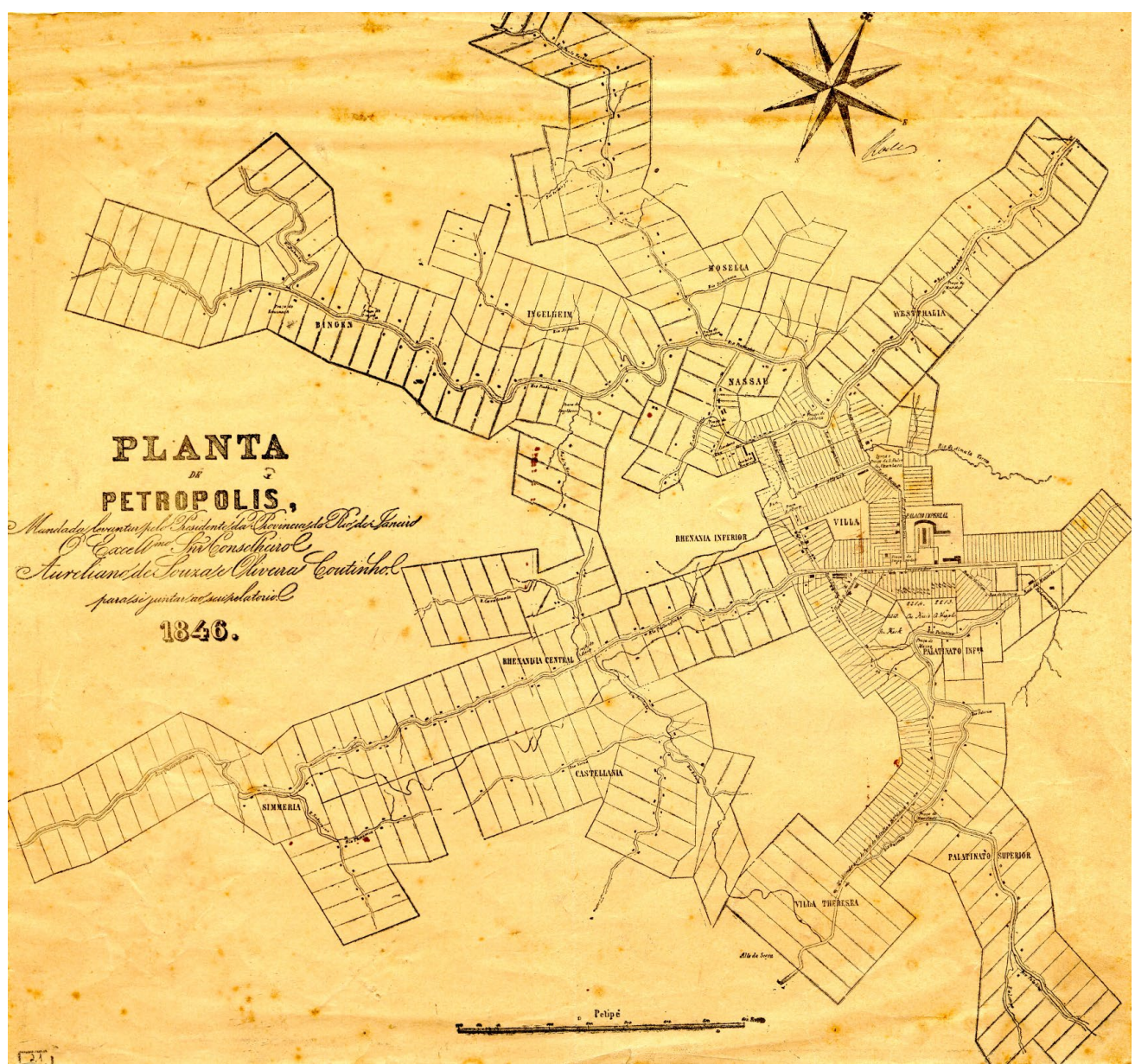

Figura 3 - Plano Koeler, 1846, onde se veem os lotes de dimensões diferenciadas organizados na malha urbana ao longo dos rios e canais. Reprodução fotográfica da Série Inventários ACI-RJ. 
Esta proteção foi compartilhada entre a Sphan e os governos do estado e do município. A Sphan tombou a área mais nobre da cidade, além de todas as calhas dos rios e canais e o conjunto fabril de Cascatinha. Essa área foi inscrita em 1982, como extensão do tombamento da Avenida Koeler, no Livro de Tombo Arqueológico, Etnográfico e Paisagístico, no Processo de Tombamento n 662-T-62. Destaca-se na proteção pela Sphan a delimitação dos entornos dos rios e canais onde se situavam os lotes agrícolas, protegendo-os com o uso desse instrumento legal. $\bigcirc$ governo estadual, por meio do Instituto Estadual do Patrimônio Cultural (Inepac), tombou outras áreas da cidade e bens pelo seu valor individual. $\bigcirc$ governo municipal assumiu outros tombamentos e o compromisso com a redução de gabaritos para as edificações novas. Dessa forma, foram considerados como valores de patrimônio outros períodos da história brasileira, a diversidade arquitetônica, paisagística e os elementos geográficos definidores da forma urbana.

No caso do centro histórico de Laguna, pioneiro no uso do conceito cidadedocumento, havia apenas um imóvel tombado pelo Iphan, desde 1954 lentão diretoria, Dphan): a Casa de Câmara e Cadeia, de arquitetura colonial. Entre os anos de 1978 até 1981, o município já havia protegido por decreto alguns imóveis de caráter excepcional além de dois sítios importantes na formação da cidade: a Praça República Juliana, onde se situa a Casa de Câmara e Cadeia, e o Largo do Rosário, "onde se encontra um dos conjuntos mais homogêneos representativo das edificações luso-brasileiras". ${ }^{35}$ Entretanto, por causa do processo de destruição do centro histórico, o prefeito da cidade solicitou o seu tombamento à Diretoria Regional da Sphan/Pró-Memória, ${ }^{36}$ no Rio Grande do Sul, então responsável pelos estados da região, dando origem ao Processo n 11 122-T-84, aberto em 1984. Ele tinha urgência na resposta porque havia emitido um decreto congelando por 90 dias a permissão para novas construções e alvarás de demolição no centro histórico.

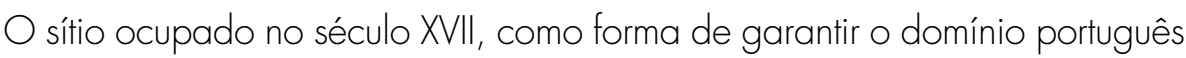
sobre o território brasileiro, apresentava arquitetura diversificada, com alguns poucos exemplares coloniais, com muitas construções do final do século XIX, de características de estilo eclético, e do início do XX, assim como prédios construídos pouco antes do pedido de tombamento, incluindo um com seis pavimentos, marcante na paisagem. A Associação Comercial e Industrial de Laguna, assim que tomou conhecimento do tombamento provisório, ainda em 1984, promoveu um abaixo-assinado no qual havia um entendimento de que apenas alguns prédios poderiam ser tombados, liberando o restante do centro histórico para transformações, incluindo construções de maior altura. Em suas palavras, o tombamento pela Sphan poderia abranger os prédios que, "pela sua natureza, não deixem dúvida quanto 
37. Processo $\mathrm{n}^{\circ}$ 1122-T1984, Laguna (1984, fl. 94).

38. Ibid. fl. 19 a sua preservação e restauração, obviamente, liberando os demais que escapem aos verdadeiros objetivos de um tombamento criterioso". ${ }^{37}$

Deve-se observar que essa visão, expressa no abaixo-assinado contra o tombamento daquele centro histórico, fazia uso dos critérios historicamente em uso pelo Iphan, de valorização de imóveis excepcionais, coloniais ou relacionados a fatos memoráveis da história. Era um modo de valorização dos bens em acordo com o quadro da memória citado por Marcia Chuva, da "centralidade mineira", acrescido da excepcionalidade histórica ou arquitetônica. Esse tipo de tensão, por um lado colocava em xeque e enfraquecia a legitimidade da iniciativa do prefeito, por outro, demonstrava a importância de construir outros modos de valoração das cidades e de criar novas referências de memória social por meio das quais os brasileiros pudessem compreender os valores de patrimônio.

Mesmo com abaixo-assinado a prefeitura e a Sphan mantiveram a defesa do tombamento, dando continuidade aos estudos para construir uma argumentação de valor nacional do sítio histórico. Essa situação exigiu um reforço na argumentação dos valores atribuídos ao sítio, cuja base metodológica fez uso do conceito de cidade-documento.

Segundo Franco, o valor, em escala nacional de Laguna, podia ser atribuído ao papel que a cidade desempenhou na ocupação do território brasileiro, "em virtude de sua localização, no processo de expansão das fronteiras meridionais; e, sobretudo, pela forma urbana assumida afinal como precipitação espacial dos dois processos precedentes". 38 Para tanto, o sítio histórico foi considerado como um todo e não apenas pelas qualidades arquitetônicas ou históricas dos prédios que compunham a malha urbana. Foram considerados os vestígios da construção da cidade em determinada situação geográfica. Para tanto, metodologicamente, o estudo de tombamento se deu pelo confronto da história com a representação da cidade nas plantas náuticas e cadastrais e pela formulação de hipóteses sobre a ocupação da localidade e relações sociais ali desenvolvidas. A cidade foi lida a partir do sítio natural que motivou a escolha de sua implantação no local, das transformações na sua ocupação, do tecido urbano e de suas edificações. Como resultado, os morros balizadores do sítio histórico e parte da laguna onde se situava o porto foram valorizados como patrimônio e incluídos no tombamento, acrescendo esses elementos à proposta inicial de delimitação do centro histórico, da Diretoria Regional do Iphan, abrangendo apenas a malha urbana e o casario (figuras 4 e 5).

Os processos de tombamento de Petrópolis e Laguna foram exemplares e pioneiros numa nova narrativa de valorização dos sítios urbanos com a inclusão de outros elementos definidores da forma urbana como patrimônio, dando um sentido cultural e histórico à geografia, às paisagens e às formas de apropriação e uso dos 
territórios. Atenderam a novas possibilidades de preservação dos espaços, superando a atribuição de valores, até então, com predominância dos estilos arquitetônicos.

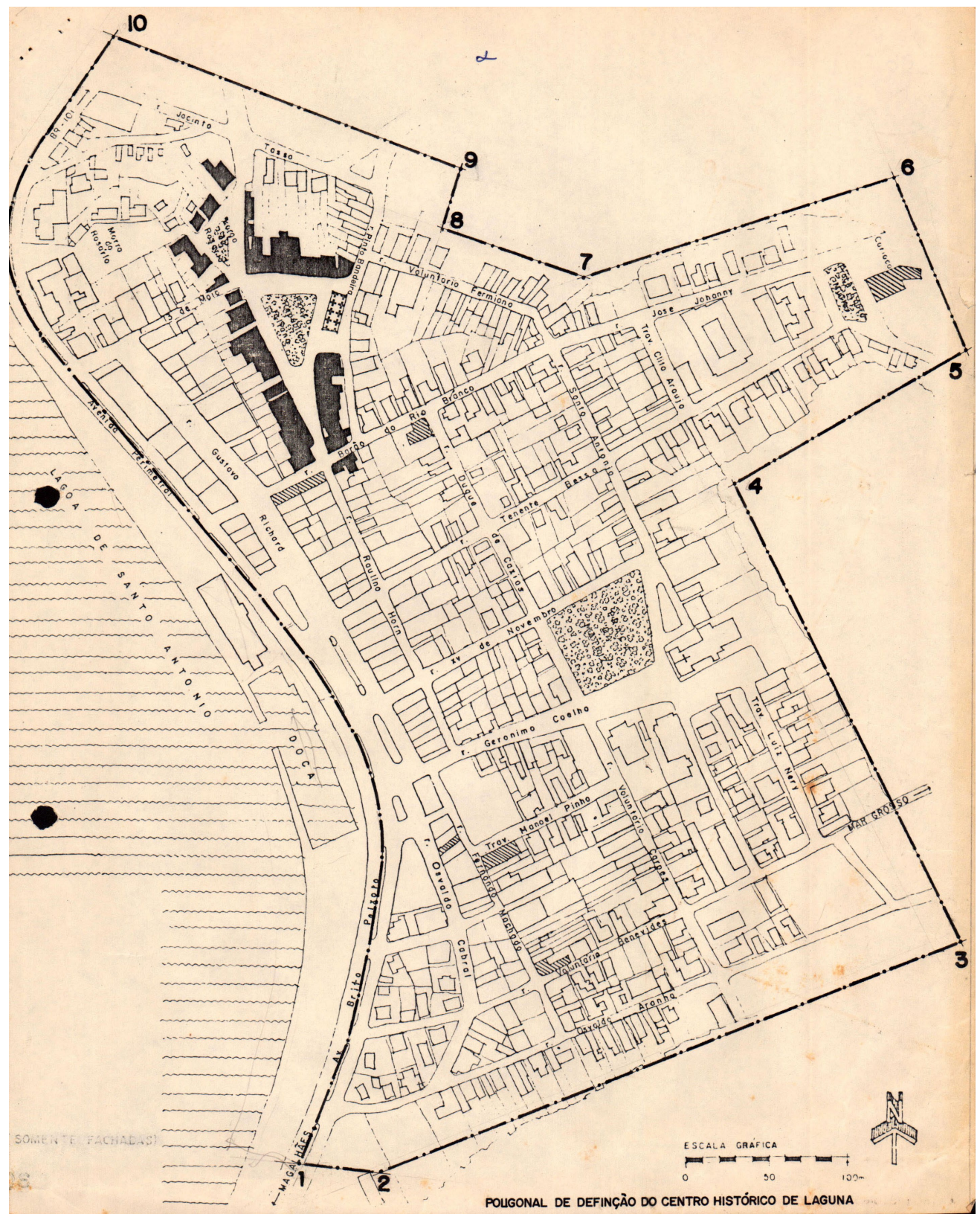

Figura 4 - Primeira delimitação do centrohistórico de Laguna, abrangendo apenas a malha urbana e o casario. Diretoria Regional do Iphan. Fonte: Processo de Tombamento, Volume 1, fl. 6. Série Tombamentos ACI-RJ. 


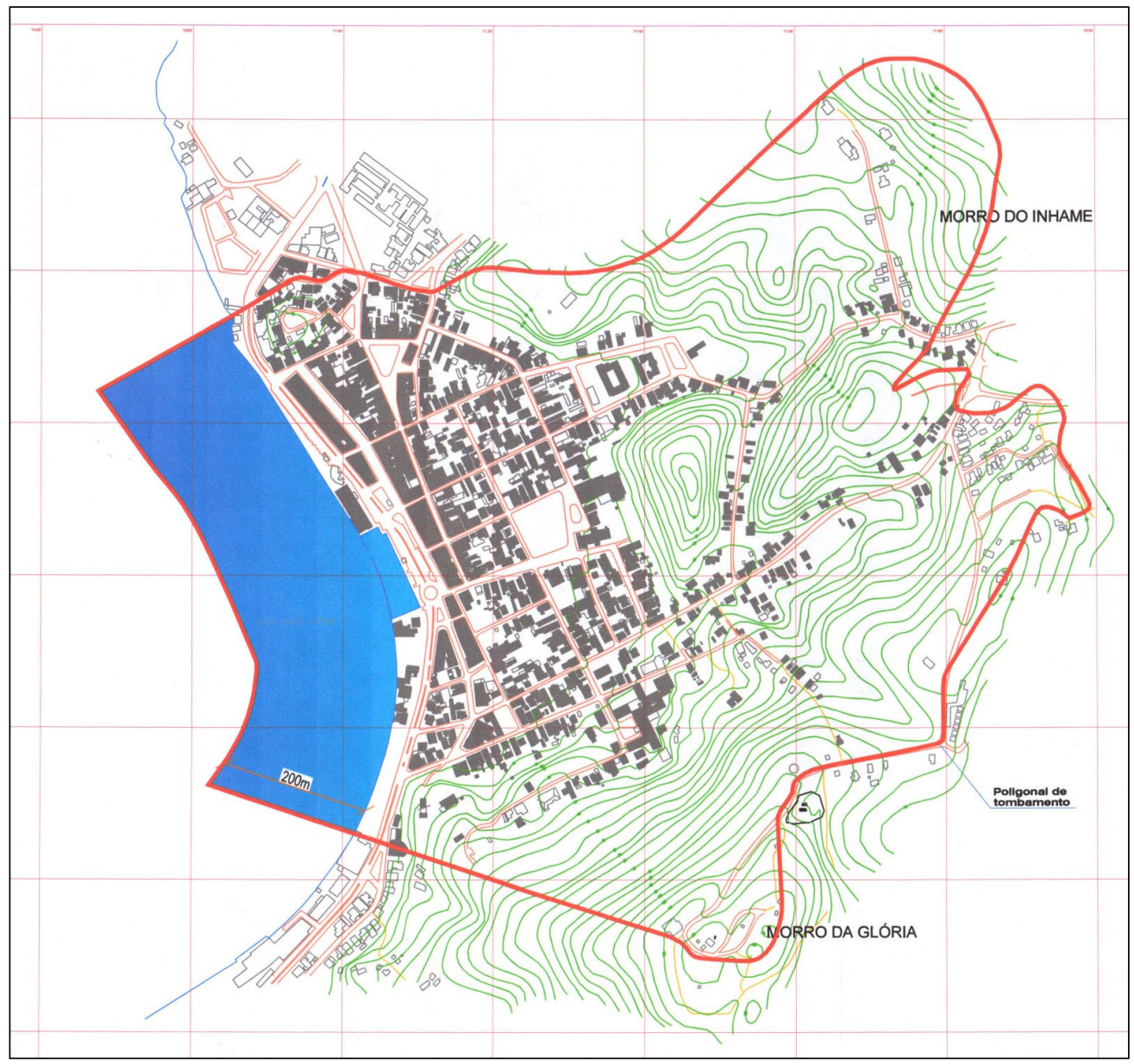

Figura 5 - Delimitação final da área tombada, marcada em vermelho, abrangendo parte da laguna e os morros. Processo de Tombamento, Anexo III, fl. 58. O desenho compõe um conjunto de plantas relativas a um estudo da cidade feito após o tombamento. Série Processos de Tombamento ACI-RJ.

Os outros dois tombamentos de sítios urbanos atendidos dentro do período estudado foram São Francisco do Sul, em Santa Catarina, a pedido do prefeito municipal e presidente da Fundação Catarinense de Cultura, e Natividade, na parte de Goiás extraída para o atual Estado de Tocantins, por iniciativa de um deputado estadual. A valorização desses dois sítios também fez uso do conceito cidade-documento.

O centro histórico e paisagístico de São Francisco do Sul foi tombado pela Sphan em 1987. Assim como Laguna, teve sua heterogeneidade arquitetônica considerada como parte do documento histórico representado pela cidade, junto com elementos geográficos delimitadores da malha urbana: três morros e parte da Baía da Babitonga. No estudo desenvolvido pela DTC, 
esses elementos, mais que os monumentos e edificações, eram referências ainda legíveis da história da cidade, não se limitando a um cenário.

A conceituação por nós dada aos elementos geográficos, portanto, está para além da ideia de cenário verde à construção urbana; faz parte, principalmente da apreensão cultural do território pelo colonizados. Essa é a razão fundamental para a inclusão dos morros do Rádio, da Caixa D'Água e do Hospício em nossos estudos e na nossa proposta de tombamento e delimitação. ${ }^{39}$
39. Processo $\mathrm{n}^{\circ}$ 1163-T1985, São Francisco do Sul/ SC (1985, fl. 25).

40. Processo $\mathrm{n}^{\circ}$ 1117-T1984, Natividade/GO [TO] (1984, fl. 126).

41. Ibid. fl. 125 .

42. Ibid. fl. 149 .

Natividade, cidade que teve origem no século XVIII com a exploração de ouro e se desenvolveu com a pecuária no século XIX, teve valores atribuídos levando em conta as características diversificadas dos imóveis e a relação com a Serra de Natividade. A respeito dos imóveis, os estudos desenvolvidos pela DTC ponderaram que "as modificações e renovações arquitetônicas introduzidas ao longo dos anos, por um lado rompem o caráter harmonioso do conjunto, por outro, introduzem um dado de contemporaneidade à cidade, fundamental à compreensão de sua dinâmica urbana". ${ }^{40}$ Esta dinâmica era resultado do período da economia da pecuária na região e, também, de transformações no século XX, quando imóveis novos foram construídos na malha urbana colonial. Os estudos valorizaram, ainda, a "vinculação histórica entre o núcleo urbano e a Serra de Natividade, por guardar, esta última, os remanescentes da atividade que deu origem à cidade (diques, canais, etc. necessários ao desenvolvimento da mineração) e abrigos pertencentes presumivelmente aos escravos" ${ }^{41}$ Com isso o tombamento deveria incluir os elementos relacionados à ocupação da área urbana e os relacionados à produção econômica presentes na serra, como a infraestrutura e os vestígios de grupos sociais que, até então, eram pouco observados nos estudos de tombamento, como os escravos desse caso.

A inscrição no Livro de Tombo Arqueológico, Etnográfico e Paisagístico, no entanto, restringiu-se ao centro histórico de Natividade. Houve um entendimento por parte da Diretoria Regional da Sphan/Pró-Memória, de que a serra já estaria "relativamente protegida pela Prefeitura Municipal, porque é onde se localiza o manancial de abastecimento de água da cidade" 42 e que faria gestões junto ao IBDF (Instituto Brasileiro de Desenvolvimento Florestal) para criar ali um parque. A respeito dessa divergência entre a Regional e a DTC pode-se observar que, embora a proteção da serra pela prefeitura e pelo IBDF pudesse ser eficiente em diversos aspectos, era de competência da Sphan a valorização e preservação de bens materiais por meio do tombamento. Tal instrumento adequa-se à atribuição de valores simbólicos aos bens, o que resulta também na valorização de seus produtores como parte da história. A exclusão do lugar, na delimitação 
43. Cf. Lia Motta (2017).

44. Estimativa feita com base em informações manual de preenchimento do INBI-SU. Cf. Rezende (2007a).

45. A planta da cidade foi produzida por Sílvio de Vasconcelos, representante do Iphan em Minas Gerais, no final da década de 1940 e encontra-se no ACI-RJ. final do tombamento foi, portanto, uma perda para o que a Sphan/Pró-Memória (ou ao menos parte da instituição) buscava praticar na ocasião.

O conceito cidade-documento está claro em dois outros processos cujos tombamentos foram concluídos na década de 1990: o conjunto arquitetônico, urbanístico e paisagístico de Cuiabá, em Mato Grosso, inscrito em três livros de tombo: no Histórico, no de Belas Artes e no Arqueológico, Etnográfico e Paisagístico, em 1993; e o conjunto arquitetônico, paisagístico e urbanístico de Penedo, em Alagoas, apresentado anteriormente, e inscrito em dois livros de tombo, no Histórico e no Arqueológico, Etnográfico e Paisagístico, em 1996. Há estudos, entretanto, que demonstram ser residual o uso desse conceito após o período comentado nesse texto, prevalecendo o critério arquitetônico, de valorização dos estilos com base no que é predominantemente consagrado pela historiografia dominante da arquitetura. Não vêm sendo considerados outros elementos de referência da formação das cidades e dos grupos sociais que as produziram. ${ }^{43}$

\section{APROXIMAÇÕES DEMOCRÁTICAS NOS SÍTIOS TOMBADOS}

No período aqui abordado foram notáveis as reivindicações de moradores e comerciantes dos sítios já tombados pelo Iphan, devido a problemas relacionados às transformações urbanas. As cidades brasileiras haviam retomado seu crescimento desde a década de 1960, devido, especialmente, à política rodoviarista do governo Juscelino Kubitschek, alcançando os sítios tombados de pequeno porte no interior, até então longe de pressões mais significativas de transformações. Ao todo, em 1979, havia 33 sítios urbanos tombados pela instituição $0^{44} \mathrm{com}$ uma quantidade significativa de imóveis residenciais, comerciais e mistos de uso cotidiano, sem monumentalidade, estando muitos em mau estado de conservação. Além das informações disponíveis no Instituto Brasileiro de Geografia Econômica (IBGE), - crescimento dessas cidades pode ser constatado nos números identificados no ACl-RJ. Em Ouro Preto, tombada em 1938, de acordo com documentos na Série Obras do ACI-RJ, verifica-se que, iá na década de 1960, a instituição recebeu 356 pedidos de aprovação de construções novas no entorno imediato da cidade e 142 pedidos de obras novas dentro da sua malha urbana original, composta por aproximadamente mil imóveis antigos, conforme registrado na planta da cidade no final da década de 1940. ${ }^{45}$ Além das construções novas, 
nesses sítios surgiram em quantidade significativa demandas de ampliação e reformas nas edificações antigas, parcelamento de lotes e novos loteamentos.

Diante do quadro descrito, os sítios urbanos que já haviam sido priorizados nas políticas públicas de preservação do governo federal desde a criação do PCH passaram a ser tema importante no desenvolvimento de ações institucionais da Sphan/Pró-Memória. Aloísio Magalhães partia da ideia de que "a comunidade é a melhor guardiã de seu patrimônio" 46 e referiu-se à necessidade de "interação" da instituição com as comunidades e à "conscientização" das pessoas sobre os valores de patrimônio. ${ }^{47}$

O livro editado pela Sphan/Pró-Memória em 1980, Proteção e revitalização do patrimônio cultural no Brasil: uma trajetória, refere-se ao avanço alcançado pelo PCH na década de 1970, com sua proposta de "reinserção dos bens recuperados no contexto socioeconômico e cultural das comunidades a que pertencem". ${ }^{48} \mathrm{~A}$ instituição, em sua nova fase, entendeu que o PCH tratava o monumento "como elemento dinâmico de uma ativa e presente trajetória histórica", ${ }^{49}$ favorecendo novos usos e sentidos a serem atribuídos aos bens por meio de apropriações contemporâneas. O texto continua estabelecendo uma relação entre a meta do CNRC, de construir um sistema referencial básico da dinâmica cultural brasileira, e os monumentos tombados. Afirma que o conhecimento produzido pelo sistema referencial seria "de óbvia importância para a coordenação entre os marcos monumentais e a história que os envolve, conduzindo os significados que lhes são atribuídos pelas correspondentes comunidades". ${ }^{50}$ Nessas afirmações ficam claras ideias orientadoras da aproximação entre os bens tombados pelo Iphan, a vitalidade urbana e sentidos atribuídos às cidades. Estas deveriam ser consideradas como bens em produção, ainda vivos, com significados no presente e objetos de constantes ressignificações pelos usuários. Os procedimentos de preservação nas cidades tombadas deveriam considerar os moradores e outros usuários dos sítios, a dinâmica urbana e a melhoria da qualidade de vida de modo relacionado à significados atribuídos aos sítios pelas comunidades.

Diante disso, entre 1979 até 1982, a instituição promoveu oito seminários nos sítios tombados de Ouro Preto/MG, Paraty/RJ, Goiás/GO, Olinda/PE, São Luís/MA, Congonhas/MG, São Cristóvão/SE e Cachoeira/BA.

O primeiro seminário, em Ouro Preto, desenvolveu-se entre os dias 19 e 21 de abril de 1979 e foi marcado pela comoção decorrente do deslizamento de encostas na cidade durante chuvas intensas no verão. Segundo reportagem no Boletim Iphan n. 3, de novembro/dezembro de 1979, essa foi a "primeira oportunidade concreta que teve a população de Ouro Preto de revelar seus anseios e fazer-se presente na discussão das soluções proposta para a cidade". ${ }^{51}$ Era
46. Magalhães (1997, p. 189).

47. Nesse período a instituição adotou o conceito de "comunidade", as ideias de "conscientização" e de "interação", estando presentes em diversos documentos.

48. Sphan/PróMemória (1980, p. 43).

49. Ibid.

50. Ibid.

51. Boletim Iphan n. 3 (1979, p.1) 
52. Os encontros, o de Cachoeira e de São Cristóvão, tiveram seus resultados publicados pela Pró-Memória. Cf. Mec.Sec.Sphan (1982a e 1982b). Os documentos produzidos nos demais seminários estão arquivados junto à documentação do Iphan. preciso, naquela ocasião, decidir sobre a recuperação dos morros e sobre a definição de novas moradias para os desabrigados. $\bigcirc$ encontro teve, portanto, o caráter de uma audiência pública, conforme entendemos hoje. A partir dessa experiência, os seminários nas outras cidades foram organizados para discutir os problemas vividos pelas populações e para o estabelecimento de pautas de reivindicações dos grupos locais. Todos os encontros contaram com a produção de documentos para registro dos problemas e reivindicações das comunidades. ${ }^{52}$

Do mesmo modo que em Ouro Preto, os demais seminários duraram, geralmente, três dias, durante os quais foram organizados grupos de trabalho e plenárias, que contaram com representantes de organizações comunitárias, moradores ou usuários dos sítios e com representantes das prefeituras, dos órgãos estaduais de cultura ou de patrimônio, de universidades, do Ministério da Educação e Cultura (figura 6). Os debates foram desenvolvidos tanto a partir de problemas específicos, como em Ouro Preto e do debate sobre o plano diretor de São Cristóvão, quanto dos problemas mais gerais que afetavam a cidade, como a necessidade de revitalização econômica e de desenvolvimento social. Nos oito centros históricos, os seminários foram acontecimentos mobilizadores das comunidades, associando a preservação com os modos contemporâneos de apropriação dos sítios, relacionando o patrimônio com o cotidiano e com as condições de vida local. Por essa concepção, entende-se que, mesmo construídos no passado, seu uso e percepção pelas comunidades thes dariam continuidade, garantindo sua permanência, relacionando-os com novos modos de vida e pelo desenvolvimento de atividades socioeconômicas. De forma diferente daquela afirmada por Sérgio Miceli, relativa à política do governo na década de 1970, tratava-se, então, de considerar as "obras e os monumentos" de modo associado com as experiências e interesses presentes e reconectá-los aos grupos sociais como sendo parte de suas histórias.

Com a morte de Aloísio Magalhães, os seminários não tiveram continuidade, mas demonstraram a importância de uma interação sistemática com os moradores dos sítios tombados. Destaca-se como diferencial desses encontros o trabalho coletivo e a preocupação com o cotidiano das populações. Até então as relações entre a instituição, os moradores e as autoridades locais eram mais restritas, resolvendo cada caso. Mesmo quando se buscou adotar soluções mais gerais para os sítios, por meio de planos diretores ou de preservação, na década de 1970, esses foram desenvolvidos por instituições estaduais ou universidades, contando muitas vezes com o Iphan, mas sem a participação efetiva das comunidades.

A preocupação com o estabelecimento de procedimentos de trabalho que considerassem as populações locais deu origem, em meados da década de 
1980, ao Inventário Nacional de Bens Imóveis em Sítios Urbanos Tombados - o

INBI-SU. Conforme dito, em face do crescimento das cidades já tombadas e do contexto da redemocratização, tornou-se necessária a produção de conhecimentos para o estabelecimento de critérios claros de preservação dos sítios urbanos, justificados e difundidos entre os interessados, especialmente os moradores, comerciantes e demais usuários dos sítios. Essa proposta, segundo entendimento da Sphan, ajudaria a superar as decisões "caso a caso" definidas pelos técnicos da instituição por carência de informações sistematizadas. $\bigcirc$ conhecimento produzido embasaria o planejamento de normas de intervenção nos imóveis. Além disso, as informações constituiriam, por si, uma ação de preservação porque ficavam registradas em outros suportes, perpetuando o saber contido nos sítios e permitindo a produção de conhecimentos por outros agentes, pela oferta dos dados agregados e individualizados em um banco de dados. ${ }^{53}$

\section{IPHAN}

O Instituto do Patrimônio Histórico e Artístico Nacional, o Governo do Estado de Pernambuco através da Secretaria de Turismo, Cultura e Esportes e da Fundação Patrimônio Histórico e Artístico de Pernambuco - FUNDARPE, a Prefeitura Municipal de Olinda, a Fundação Roberto Marinho e a Sociedade dos Moradores e Amigos de Olinda Antiga se reuniram no patrocínio do Encontro em Defesa do Patrimônio Cultural de Olinda, realizado na Igreja da Sé, no período de 30 de novem bro a 2 de dezembro. Contando com um documen to básico que tratava do patrimônio natural, urbano e histórico, o Encontro, que previa o trabalho de comissões para aprovação de documento final em reunião plenária, recriou, no momento de sua concretização, sua trajetória, seus objetivos. Era. . .

\section{a Associação dos Moradores discutindo o seu espaço}

Figura 6 - Recorte do Boletim Iphan novembro/dezembro de 1979, com chamada da notícia sobe o seminário realizado em Olinda. Acervo da Biblioteca Noronha Santos - Iphan.

No novo contexto da redemocratização, já com melhores condições institucionais para desenvolvimento de trabalhos nos sítios urbanos, além do estabelecimento de parâmetros de valorização e critérios detalhados de intervenção nos imóveis dos sítios tombados, de caráter urbanístico e arquitetônico, cabia rever os valores atribuídos na ocasião dos tombamentos. Muitos desses sítios foram protegidos como cidade-monumento, ${ }^{54}$ acreditando-se que não seriam submetidos às pressões de crescimento, sem sequer contarem com a delimitação das áreas tombadas ou explicitação dos valores paisagísticos e geográficos que davam sentido 
55. O registro das primeiras experiências do INBI-SU consta da entrevista com Sidney Solis e Lia Motta no Boletim Sphan/PróMemória ${ }^{\circ}$ 39, jan./fev. 1988, p. 11-13.

56. O trabalho Fundamentos e Propostas de Critérios e Normas de Intervenção Projeto Piloto: Sítio Histórico de Tiradentes foi publicado pelo Iphan em $1994 \mathrm{e}$ pelo Senado Federal em 2007. Cf. Rezende (2007b). à ocupação do território e ao casario. Para tanto, também no caso do INBI-SU foi adotado o conceito cidade-documento, pelo qual era necessário um certo nível de detalhamento das pesquisas, tanto para os critérios de intervenção como para compreensão das cidades como documento. As pesquisas incluíam a documentação arquivística e bibliográfica, os levantamentos dos imóveis que compunham os sítios e a aplicação de questionários com moradores e comerciantes usuários dos imóveis. A opção pelo levantamento dos lotes e edificações justificou-se por terem sido considerados como a célula mínima de construção das cidades e, mais que isso, objeto da limitação do direito de propriedade por seu significado cultural coletivo.

$\bigcirc$ INBI-SU, assim como outros inventários, foi organizado em fichas para sistematização das informações levantadas. Sua organização permitia agilidade na execução por equipes de campo e nos escritório da Sphan/Pró-Memória, assim como aquelas dedicadas ao levantamento da história local, demonstrando desde as primeiras aplicações em 1987, em Ouro Preto e São Luís, ser possível inventariar, em média, três casas e meia por equipe de três pessoas, a cada dia. ${ }^{55}$ Esta rotina foi confirmada ao longo do desenvolvimento do Inventário, principalmente quando contou com recursos do Programa Monumenta, no final da década de 1990 e início dos anos 2000.

Resultados importantes foram alcançados na aplicação desse inventário, destacando-se os Fundamentos e Propostas de Critérios e Normas de Intervenção Projeto Piloto: Sítio Histórico de Tiradentes, em Minas Gerais, concluído em 1994.56 Neste trabalho foi possível delimitar setores para aplicação de critérios urbanísticos e arquitetônicos de preservação, de acordo com seu papel na ocupação do território, suas características geomorfológicas e significados como patrimônio cultural.

No decorrer do inventário foram promovidos encontros com os moradores e vereadores de Tiradentes para esclarecimentos sobre seus objetivos e na conclusão dos trabalhos foi organizada uma exposição no Fórum da cidade, para apresentação dos resultados (figura 7).

Um resultado destacado nas avaliações do INBI-SU foi a troca de conhecimentos durante os levantamentos dos imóveis, que provocavam reflexões sobre valores atribuídos pelos habitantes e as razões técnicas da preservação. Independentemente do alcance de um resultado final na aplicação do inventário, os procedimentos das pesquisas e levantamentos resultavam na interação da instituição com os grupos sociais locais, podendo ser considerado como um procedimento de educação patrimonial. A esse respeito, o Manual do INBI-SU afirma: 
Observou-se na experiência de campo nos diversos sítios onde o inventário já foi iniciado, que o contato com a população durante a visita a cada edificação tem revelado uma dinâmica própria, independente da conclusão dos levantamentos. $\bigcirc$ trabalho instaura um processo de reflexão sobre o sentido da preservação ao promover a relação direta do IPHAN com as comunidades, através da participação dos moradores que disponibilizam suas casas ao trabalho técnico da instituição e são solicitados a dar suas opiniões. ${ }^{57}$

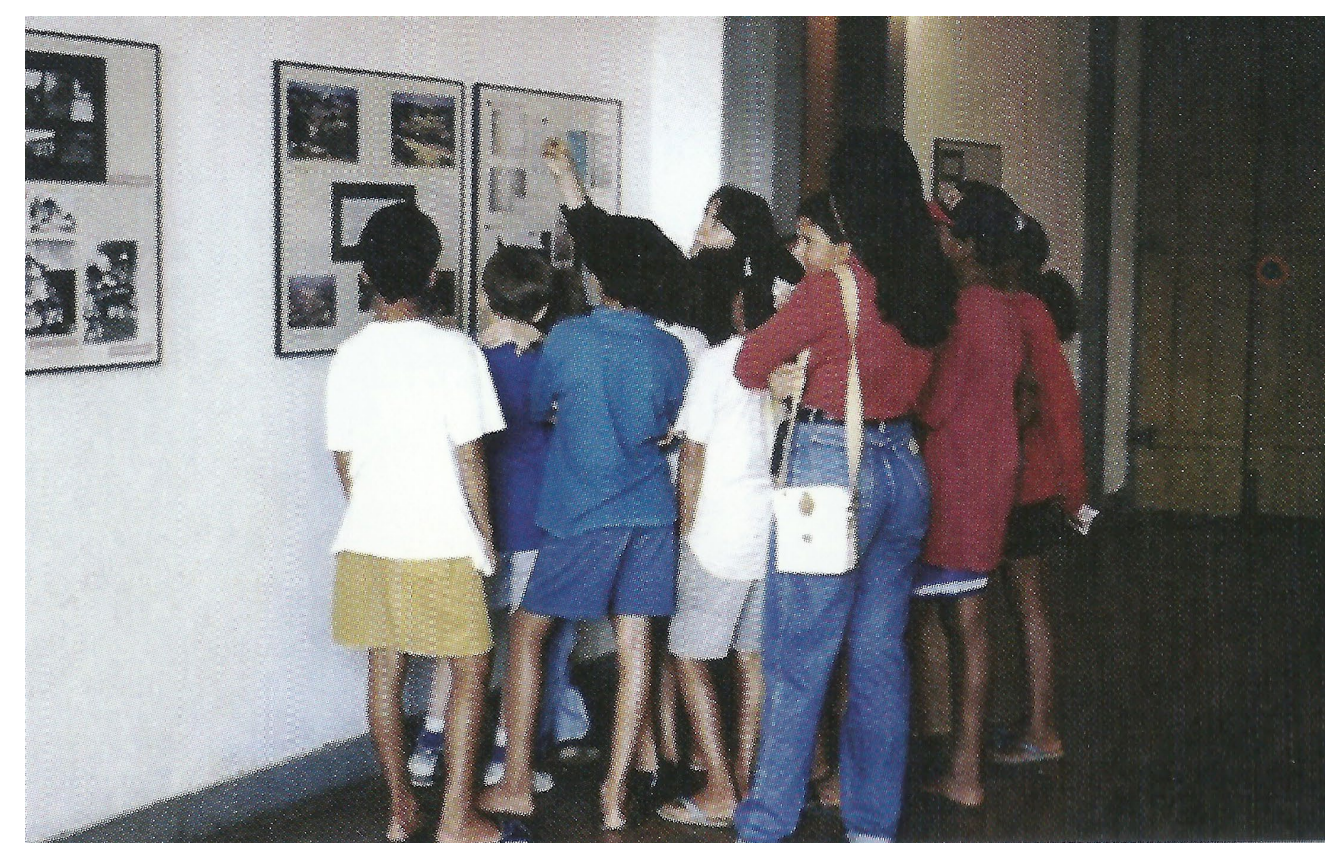

Figura 7 - Exposição organizada em 1994, no Fórum da de Tiradentes/MG, para entrega à população do trabalho. Fundamentos e Propostas de Critérios e Normas de Intervenção - Projeto Piloto: Sítio Histórico de Tiradentes. Foto: Isabel Câmara. Acervo do INBI-SU/Iphan.

Mesmo tendo sido interrompido pela instituição, em 2004, o INBI-SU mostrouse metodologicamente viável e importante caminho na valorização das cidades, contribuindo para um patrimônio ampliado naquele momento e para relações democráticas de preservação, por contarem com a produção de conhecimentos e com a explicitação dos valores atribuídos, condição para o estabelecimento de diálogos entre moradores, usuários e instituições e para evitar decisões equivocadas, ou mesmo autoritárias, por falta de conhecimento sobre os bens. 
58. Cf. Brasil (1988).

59. Cf. Senado Federal (s. d.).

\section{CONCLUSÃO}

que se pode destacar dessa trajetória é a atenção dada pelo Iphan às demandavam sociais pela proteção de sítios urbanos, assim como aos habitantes dos conjuntos já tombados diante de seus anseios pela solução de problemas cotidianos relacionadas à preservação. Houve esforços para avançar na proteção do patrimônio das cidades, por meio da valorização de seus aspectos documentais, da produção e sistematização de conhecimentos a seu respeito e do estabelecimento de diálogos com moradores de sítios tombados. Estes esforços, em sintonia com outros relacionados às reivindicações de grupos afrodescendentes, indígenas e populares, também fortalecidos nos anos 1970 e 1980, contribuíram para que, pela primeira vez, uma Constituição Federal definisse um conceito de patrimônio. $\bigcirc$ Artigo 216 da Constituição de 1988 determina que "constituem patrimônio cultural brasileiro os bens de natureza material e imaterial, tomados individualmente ou em conjunto, portadores de referência à identidade, à ação, à memória dos diferentes grupos formadores da sociedade brasileira". ${ }^{58}$ Estabeleceu com isso a base legal para novos parâmetros de valorização e proteção de bens culturais, a partir dos quais devem ser considerados os grupos sociais para os quais fazem sentido.

Deve-se lembrar de que antes disso as constituições federais apenas descreviam os tipos de bens passíveis de proteção como patrimônio pelo seu interesse histórico, artístico, beleza ou particularidades excepcionais no caso das paisagens ou localidades. Na Constituição de 1934, primeira a tratar do tema do patrimônio, foi definido que "cabe à União, aos Estados e aos Municípios [...] proteger os objetos de interesse histórico e o patrimônio artístico do País. Nas constituições seguintes foram acrescidos outros bens: em 1937, "os monumentos [...] naturais, assim como as paisagens ou os locais particularmente dotados pela natureza"; em 1946, os "documentos" e "as paisagens e os locais dotados de particular beleza", e em 1967 os "locais de valor histórico ou artístico" e as "jazidas arqueológicas". 59 Essa posições se mantiveram em 1988, quando, além da definição do conceito de patrimônio, o mesmo Artigo 216 incluiu novos bens passíveis de proteção, tais como formas de expressão e modos de criar, fazer e viver.

$\bigcirc$ que mais importa, entretanto, é que, conceitualmente, a Constituição Federal de 1988 determina que qualquer bem constituirá patrimônio brasileiro quando a ele for atribuído valor como referência de grupos sociais. Conforme disse Maria Cecília Londres Fonseca, alguns anos depois, a valorização das referências culturais dos grupos pressupõe os "sujeitos para os quais essas 
referências fazem sentido (referências para quem?). Essa perspectiva veio deslocar o foco dos bens [...] para a dinâmica de atribuição de sentidos e valores" ${ }^{\prime 6}$

Pode-se então assumir que a concepção constitucional de patrimônio foi a principal herança daquele período. Herança que favorece ao atendimento de pedidos de proteção de bens feitos por agentes externos às instituições de patrimônio e, também, às instituições em trabalhos que considerem os múltiplos aspectos dos sítios urbanos como expressões materiais dos diferentes grupos sociais, independentemente de determinada estética ditada pelos estilos consagrados. Mais do que isso, indica caminhos para uma ação proativa do poder público na identificação e proteção de bens significativos para diferentes coletividades, de modo a valorizá-las como representantes da identidade brasileira.

Ter a década de 1980 em perspectiva contribui para a continuidade dos esforços feitos naquele período, necessários porque, mesmo com a ampliação da concepção de patrimônio, ainda hoje predominam os critérios de valorização relacionados à historiografia dominante da arquitetura, comprometendo práticas mais amplas de preservação das cidades. 


\section{REFERÊNCIAS}

FONTES ICONOGRÁFICAS

AUguSTO, Antônio. Petrópolis vista do Morro do Caxambu: devastação imobiliária. Rio de Janeiro, 1986. Série Inventário, ACI-RJ. 1. Fotografia.

CÂMARA, Isabel. Exposição organizada em 1994, no Fórum da de Tiradentes/MG, para entrega à população do trabalbo Fundamentos e Propostas de Critérios e Normas de Intervenção - Projeto Piloto: Sítio Histórico de Tiradentes. Tiradentes, 1994. Acervo do INBI-SU/Iphan. 1. Fotografia.

DELIMITAÇÃO FINAL DA ÁREA TOMBADA DO CENTRO HISTÓRICO DE LAGUNA. Rio de Janeiro, [s. d.]. Processo de Tombamento, Anexo III, fl. 58. Série Processos de Tombamento ACI-RJ.

LIMA, Viana de. Vista de Penedo/AL a partir do Rio São Francisco. Rio de Janeiro, 1976. Relatório de Missão da Unesco, ACI-RJ. 1. Fotografia.

PLANO KOELER. 1846. Reprodução fotográfica da Série Inventários ACI-RJ.

PRIMEIRA DELIMITAÇÃO DO CENTRO HISTÓRICO DE LAGUNA. Rio de Janeiro, [s. d.]. Diretoria Regional do Iphan. Processo de Tombamento, v. 1, fl. 6. Série Tombamentos ACI-RJ.

LIVROS, ARTIGOS E TESES

ANDRADE, Rodrigo M. F. de. Rodrigo e o Sphan - coletânea de textos. Rio de Janeiro: Sphan/Pró-Memória, 1987.

AZEVEDO, Paulo Ormindo de. PCH: a preservação do patrimônio cultural e natural como política regional e urbana. In: Anais do Museu Paulista. São Paulo. N. Sér. v. 24. n. 1. p. 237-256. jan-abr. 2016.

BLOCH, Marc. Introdução à História. Sintra/PT: Publicações Europa América, 1965 (Coleção Saber).

BOLETIM IPHAN n 3. Rio de Janeiro: nov./dez., 1979, p. 1-4. Disponível em: <https://bit. ly/38Vchim>. Acesso em: nov. 2019. 
BOLETIM SPHAN/Pró-Memória ${ }^{\circ}$ 39. Rio de Janeiro: jan./fev. 1988, p. 11-13. Disponível em: $<$ https://bit.ly/2OsVhq5>. Acesso em: nov. 2019.

BOSCHI, Renato; VAlADARES, Lícia do Prado, Movimentos Associativos de Camadas Populares: análise comparativa de seis casos. In: BOSCHI, Renato (org.). Movimentos Coletivos no Brasil Urbano. Rio de Janeiro: Zahar Editores, 1983, p. 103-144. (Debates Urbanos).

BOSCHI, Renato. A nova classe média na política: associações de bairro. In: BOSCHI, Renato. $A$ arte da associação. São Paulo: Vértice, 1987.

BRASIL. Presidência da República. Constituição da República Federativa do Brasil. Brasília, 1988. Disponível em: <https://bit.ly/3em7uYk>. Acesso em: dez. 2019.

CHUVA, Márcia. Os arquitetos da memória: a construção do patrimônio histórico e artístico nacional no Brasil - anos 30 e 40. 1998. Tese (doutorado) - Universidade Federal Fluminense, Niterói, 1998.

FONSECA, Maria Cecília Londres. Referências Culturais: base para novas políticas de patrimônio. In: FONSECA, Maria Cecília Londres. O registro do patrimônio imaterial: dossiê final da atividade da comissão e do grupo de trabalho patrimônio imaterial. Brasília: MinC/Iphan, 2003.

FRANCO, Luiz Fernando P. N. Por uma história da forma urbana. A análise de uma amostra de tecido do centro histórico de Belém. In: Desenho urbano: Anais do II SEDUR - Seminário sobre desdenho urbano no Brasil (2: 1986: Brasília, DF). São Paulo: PINI; Brasília: CNPq; Rio de Janeiro: FINEP, 1986, p. 330-339.

HALBWACHS, Maurice. A memória coletiva. São Paulo: Revista dos Tribunais, 1990.

IPHAN - Instituto do Patrimônio Histórico e Artístico Nacional. Bens tombados e processos de tombamento em andamento. Atualização: 16 mar. 2016. Disponível em: <https://bit. ly/2B1riTm>. Acesso em: jun. 2017.

JARAMILLO, Maria Matilde Villegas. Entre os Morros e a Lagoa: Laguna Cidade Documento, 2016. 303 fls. Dissertação (Mestrado em Preservação do Patrimônio Cultural) - Iphan, Rio de Janeiro, 2016.

LE GOFF, Jacques. Documento/monumento. In: Enciclopédia Einaudi. Lisboa: Imprensa Nacional, 1984. v.1 Memória-História, p. 95-106.

MAGALHÃES, Aloísio. E Triunfo? A questão dos bens culturais no Brasil. Rio de Janeiro: Nova Fronteira; Brasília: Fundação Nacional Pró-Memória, 1997. 
MEC.SEC.SPHAN. Seminário sobre a preservação e valorização do patrimônio cultural e natural: São Cristóvão, 1982. Rio de Janeiro: Pró-Memória, 1982.

MEC.SEC.SPHAN. Seminário sobre a preservação e valorização do patrimônio cultural $e$ natural: Cachoeira, 1982. Rio de Janeiro: Pró-Memória, 1982a.

MICELI, Sérgio. Teoria e prática da política cultual no Brasil. In: MICELI, Sérgio. Estado $e$ Cultura no Brasil. São Paulo: Delfi, 1984. p. 97-112.

MOISÉIS, José Álvaro; MARTINEZ-ALIER, Vera. A Revolta dos suburbanos. In: MOISÉIS, José Álvaro; MARTINEZ-ALIER, Vera. Contradições urbanas e movimentos sociais. Rio de Janeiro: Cedec: Paz e Terra, 1978. p. 13-63.

MOTTA, Lia. Patrimônio urbano memória social: práticas discursivas e seletivas de preservação cultural - 1975 a 1990. 2000. 168 f. Dissertação (Mestrado em História Social e Documentação) - Universidade Federal do Estado do Rio de Janeiro (Unirio), Rio de Janeiro, 2000.

MOTTA, Lia. Sítios Urbanos e Referência Cultural: a situação exemplar da Maré. Rio de Janeiro, 2017. Tese (Doutorado em Urbanismo) - Faculdade de Arquitetura e Urbanismo, Universidade Federal do Rio de Janeiro, Rio de Janeiro, 2017.

NASCIMENTO, Flavia Brito do. Arquitetos Modernistas. In: REZENDE, Maria Beatriz; GRIECO, Bettina; TEIXEIRA, Luciano; THOMPSON, Analucia (Orgs.). Dicionário Iphan de Patrimônio Cultural. Rio de Janeiro, Brasília: Iphan/DAF/Copedoc, 2015. (Verbete). Disponível em: https://bit.ly/2AV2kEY. Acesso em: dez. 2019.

PLANO de conservação, valorização e desenvolvimento de Ouro Preto e Mariana. Belo Horizonte: Fundação João Pinheiro: FJP, 1975.

PLANO urbanístico de São Cristóvão. UFBA - Universidade Federal da Bahia. Salvador: UFBA. 1980.

PROJETO Petrópolis - planejamento e preservação. Fundrem - Fundação para o Desenvolvimento da Região Metropolitana do Rio de Janeiro. Rio de Janeiro: Fundrem, 1982.

QUINTAS, José Silva. Depoimento de José Silva Quintas. Ministério da Cultura, Instituto do Patrimônio Histórico e Artístico Nacional. Departamento de Promoção. Rio de Janeiro: Iphan, 1994. (Memória Oral. 6). 
RABELLO, Sonia. O tombamento. In: REZENDE, Maria Beatriz; GRIECO, Bettina; TEIXEIRA, Luciano; THOMPSON, Analucia (Orgs.). Dicionário Iphan de Patrimônio Cultural. Rio de Janeiro, Brasília: Iphan/DAF/Copedoc, 2015. (Termo chave Tombamento). Disponível em: <https://bit.ly/2On0aRI>. Acesso em: dez. 2019.

REZENDE, Maria Beatriz (Org.). Cidades históricas: inventário e pesquisa - manual de preenchimento. Brasília: Edições do Senado Federal; Rio de Janeiro: Iphan/Copedoc, 2007a. v. 82.

REZENDE, Maria Beatriz (Org.). Cidades histórica: inventário e pesquisa - Tiradentes. Brasília: Edições do Senado Federal; Rio de Janeiro: Iphan/Copedoc, 2007b. v. 83.

REZENDE, Maria Beatriz et al. Fundação Nacional Pró-Memória. In: REZENDE, Maria Beatriz; GRIECO, Bettina; TEIXEIRA, Luciano; THOMPSON, Analucia. (Orgs.). Dicionário Iphan de Patrimônio Cultural. Rio de Janeiro, Brasília: Iphan/DAF/Copedoc, 2015. (verbete). Disponível em: <https://bit.ly/2ZnJW0S>. Acesso em: dez. 2019.

RUBINO, Silvana. O Mapa do Brasil passado. Revista do Patrimônio Histórico e Artístico

Nacional, n. 24. Iphan, Rio de Janeiro, 1996.

SANT'ANNA, Marcia. Da cidade Monumento à Cidade Documento. A norma de preservação de áreas urbanas no Brasil: 1937-1990. Salvador: Oiti, 2014.

SENADO FEDERAL. Constituições brasileiras [on-line]. [s. d.]. Disponível em: <https://bit. ly/2Om6kSf>. Acesso em: dez. 2019.

SPHAN/Pró-Memória. Proteção e revitalização do patrimônio cultural no Brasil: uma trajetória. Secretaria do Patrimônio Histórico e Artístico Nacional - Sphan. Brasília: Sphan; Pró-Memória, 1980.

\section{PROCESSOS DE TOMBAMENTO}

ARQUIVO CENTRAL DO IPHAN - SEÇÃO RIO DE JANEIRO

0662-T-1962 Avenida Koeler. (Extensão do tombamento 1980 e 1982). Petrópolis/RJ.

847-T-1973 Lençóis/BA

1029-T-1980 Largo das Mercês e área de entorno. Belém/PA. 
1066-T-1982 Xapuri/AC.

1066-T-1982 Vila Porto Acre/AC.

1071-T-1982 Cidade Velha e Campina. Belém/PA

1097-T-1983 Paranaguá/PR.

1111-T-1984 Vila Operária em Delmiro Gouveia. Delmiro Gouveia/AL.

1117-T-1984 Natividade/GO [TO].

1122-T-1984 Laguna/SC.

1134-T-1984 Distrito de São Gonçalo do Rio das Pedras. Serro/MG.

1163-T-1985 São Francisco do Sul/SC.

1180-T-1985 Cuiabá/MT.

1182-T-1985 Corumbá/MS.

1201-T-1986 Penedo/AL.

1208-T-1986 Praça Fausto Cardoso e Av. Barão do Rio Branco. Aracajú/SE.

1215-T-1986 Distrito de Ribeirão da Ilha. Florianópolis/SC.

1240-T-1987 Vila das Ferradas. Itabuna/BA.

1242-T-1987 Vila Operária em Fernão Velho. Maceió/AL.

1250-T-1987 Jardim América, Jardim Europa, Jardim Paulista e Jardim Paulistano. São Paulo/SP.

1252-T-1987 Vila Ferroviária de Paranapiacaba. Santo André/SP. 
1258-T-1987 Vila da Estrela e Vila Inhomirim. Magé/RJ.

1261-T-1988 Paranaguá/PR.

1273-T-1988 Distrito de Ribeirão da Ilha. Florianópolis/SC.

1288-T-1989 Laranjeiras/SE.

Artigo apresentado em 28/1/2020. Aprovado em 27/4/2020.

\section{(cc) BY}

All the contents of this journal, except where otherwise noted, is licensed under a Creative Commons Attribution Licens 